\title{
Conservative Rehabilitation Treatments of Iliotibial Band Syndrome: A Systematic Review
}

\author{
S. Miccio ${ }^{1}$, A Berardi ${ }^{2}$, M. Tofani ${ }^{3}$, G. Galeoto ${ }^{4}$ \\ 1 Sapienza University of Rome, Rome, Italy \\ 2 Department of Human Neurosciences, Sapienza University of Rome, Rome, Italy \\ 3 Neurorehabilitation Unit, Department of Neurosciences and Neurorehabilitation Bambino Gesù Children's \\ Hospital, Rome, Italy \\ ${ }^{4}$ Department of Public Health, Sapienza University of Rome, Rome, Italy
}

\section{CORRESPONDING AUTHOR:}

\section{Galeoto Giovanni}

Department of Public Health

Sapienza University of Rome

Piazzale Aldo Moro 5

00185 Rome, Italy

E-mail: giovanni.galeoto@uniroma1.it

\section{DOI:}

10.32098/mltj.01.2021.04

LEVEL OF EVIDENCE: 1

\begin{abstract}
SUMMARY
Background. Iliotibial band syndrome (IBS) one of the most common injury of the lateral knee. This is an overuse injury, and it has an increased occurrence rate in populations favouring running and other multidisciplinary endurance sports. In many cases, the pain quickly subsides upon cessation of activities. For this reason, rehabilitation plays an essential role in reducing days of inactivity.

Objective. The purpose of this study is to evaluate the qualitative results of conservative rehabilitation treatments of IBS.

Methods. The following four electronic databases were systematically searched from March to May 2020: Medline, PEDro, Scopus and Web of Science. Papers included in the study met the following prerequisites: experimental studies with or without a control group about conservative treatments of IBS.

Titles, key words, and abstracts identified through the databases were screened independently by two reviewers/searchers. Duplicates were first eliminated from the total number of studies found in the literature through the four databases. Subsequently, after reading the title and abstract, studies against the inclusion criteria were eliminated.

Two reviewers independently extracted patient demographics and descriptive information. These characteristics were judged on the basis of information provided in the reports on the studies. Study quality and risks of bias were assessed using the Jadad scale and Pedro scale.

Results. Twelve experimental studies were included in this systematic review. Three of these are Radomized Controlled Trials three are pre-post-test and six are case reports and case series.

Conclusions. IBS responds positively to conservative treatment. More precisely, in the acute phase, shockwaves can be used, and rest and ice are recommended. Stretching and strengthening exercises should be started after the acute phase. Mulligan techniques on the hip and knee can also be used to treat iliotibial band syndrome.
\end{abstract}

\section{KEY WORDS}

Iliotibial band syndrome; iliotibial band friction syndrome; prevention; systematic review; rehabilitation.

\section{INTRODUCTION}

Iliotibial band syndrome is a non-traumatic overuse injury and is the most common cause of lateral knee pain in runners (1), with an incidence rate of $22.2 \%$ in all lower extremity injuries in runners $(2,3)$. It is a condition that affects about
$7-14 \%$ of runners (4); however, it is associated with a variety of activities, including cycling, hockey, swimming, rowing, basketball, tennis and soccer $(5,6)$. The iliotibial band (ITB) is a thick fascia that originates from the tubercle of the iliac crest, the tensor fascia latae (TFL) and the lateral gluteal 
muscles. It then passes distally and attaches to the retinaculum patellae lateralis, Gerdy's tubercle and the proximal fibular head (7).

TFL is an abductor and lateral hip stabilizer that limits hip adduction and internal knee rotation (8). Some authors (9) have shown that increases in hip adduction and internal rotation of the knee can lead to an increased tension on the iliotibial band and friction on the lateral femoral epicondyle. MacMahon et al. (10) have identified abductor weakness as one of the main causes of the development of this pathology. Iliotibial band syndrome has a multifactorial aetiology and includes intrinsic factors related to biomechanical and muscular components and extrinsic factors such as the sudden increase in workloads and distances (11).

Iliotibial band syndrome is caused by repetitive flexion/ extension of the knee, resulting in friction between the distal portion of the ITB and the lateral femoral condyle. Orchard $e t$ al. (1996) described an "impingement zone" occurring at, or slightly below, $30^{\circ}$ of knee flexion during foot strike and the early stance phase of running. During this impingement period in the running cycle, eccentric contraction of the tensor fascia latae muscle and of the gluteus maximus muscle causes the leg to decelerate, generating tension in the ITB (12).

Athletes with iliotibial band syndrome typically complain of a sharp or burning pain roughly $2 \mathrm{~cm}$ superior to the lateral joint line occurring during exercise in repeated knee extension flexion movements, stopping the activity (3).

Iliotibial band syndrome is a clinical diagnosis, and most often additional diagnostic studies are not necessary (2), especially after assessing a patient's medical history.

In 2019, a systematic review with meta-analysis on ITB Friction Syndrome to evaluate lower-limb biomechanics and conservative treatment was conducted, however, this study considered MEDLINE, CINAHL, SPORTSDiscus, Web of Science, and Google Scholar (13) using some not indexed database and evaluating different types of outcomes The aim of this review is to include studies in from indexed databases and to identify the most effective and used conservative treatments to improve the clinical condition of patients with iliotibial band syndrome. This will ideally lead to the elimination of painful symptoms and promote an early return to sports, directing work only towards physiotherapy rehabilitation.

\section{METHODS}

The research group was composed of medical doctors and rehabilitation professionals from the Sapienza University of Rome and from the Rehabilitation and Outcome Measure Assessment (ROMA) Association, which conducted the study $(14,15,24-28,16-23)$.

\section{Protocol and registration}

After registering the protocol on Prospero, this review was conducted in compliance with Preferred Reporting Items for Systematic Reviews and Meta-Analyses (PRISMA) Checklist. The registration number of this systematic review is CRD42019135447, while the reference link is https:// www.crd.york.ac.uk/PROSPERO.

\section{Eligibility criteria}

Patients with iliotibial band syndrome were the participants in this research, without restrictions regarding age, sex, and sports practice. Experimental studies with or without a control group published in English before May 2020 about physiotherapy conservative treatments of iliotibial band syndrome have been included. The main outcomes are the improvement of the clinical condition, pain, and a return to the Activities of Daily Living (ADL) and sports activity. Observational studies and studies focused on surgical and invasive treatments have been excluded.

\section{Search strategy}

The following electronic databases were systematically searched from March to May 2020: Medline, PEDro, Scopus and Web of Science. The databases mentioned were consulted with the following keywords: "iliotibial band syndrome" and "iliotibial band friction syndrome".

\section{Study selection}

Titles, keywords and abstracts identified through the databases were screened independently by two reviewers/searchers. Duplicates were first eliminated from the total number of studies found in the literature through the four databases. Subsequently, after reading the title and abstract, studies against the inclusion criteria were eliminated. The last selection process was carried out by reading the full text. After the first screening, the primary reviewer selected the relevant studies and assessed them against the inclusion criteria. Then, a second reviewer cross-checked the studies. After the second screening, studies were systematically excluded that did not meet the inclusion criteria, while others were identified that appeared pertinent. A final list of studies that were eligible for inclusion was compiled, and any disagreements were resolved by a third reviewer or by consensus. The studies that met the criteria were then subject to full text review in order to decide whether to include them in the review. 


\section{Data collection and data items}

Two reviewers independently extracted patient demographics and descriptive information. These characteristics were judged on the basis of information provided in the reports on the studies.

\section{Assessment of risk of bias}

The Randomized Controlled Trials (RCT)'s content and methodology were analysed qualitatively. Aspects of validity were defined, and a checklist was used to determine which aspects had been evaluated. Study quality and risk of bias were assessed using the Jadad scale and Pedro scale. Concerning the Jadad Scale, the total score can vary from 0 to 5 and is considered to be a good quality RCT with a score $\geq 3$. The Pedro scale instead consists of 11 items.

\section{RESULTS}

\section{Study selection}

Starting from 1,653 articles, a total of 12 were included after the selection process was completed. This selection process is shown in the flowchart below (figure 1).

\section{Study characteristics}

Twelve experimental studies were included in this systematic review. Three are RCT, three are pre-post-test and six are case reports and case series.

Being an overload disease, iliotibial band syndrome affects an active population, in most cases represented by runners. The majority of the participants were women, especially in the case reports and case series, while the male/female ratio was homogeneous in the case of pre-post tests and randomized clinical trials. The age of the participants varies from a minimum of 19 to a maximum of 43 , with an average of about 33 years.

From the summary of the studies, several treatment modalities used for this pathology have been found, many of which have demonstrated good results for reducing pain and encouraging a return to sports. In particular, the most used treatments were: muscle strengthening of the hip abductor, either as the main intervention (29-31) or as an integral part of the rehabilitation programme $(7,32-34)$, and manual therapy techniques $(7,35-37)$. Other types of treatments were: use of shockwave physical therapy (7), correction of running biomechanics through targeted programs $(33,38)$, correction of malfunctioning muscle and joint downstream and upstream of the knee with a multifaceted approach

Records identified through database searching $(n=1653)$ (586 PubMed, 771 Scopus, 281 Web of Science, 15 PEDro)

Additional records identified

through other sources $(n=0)$

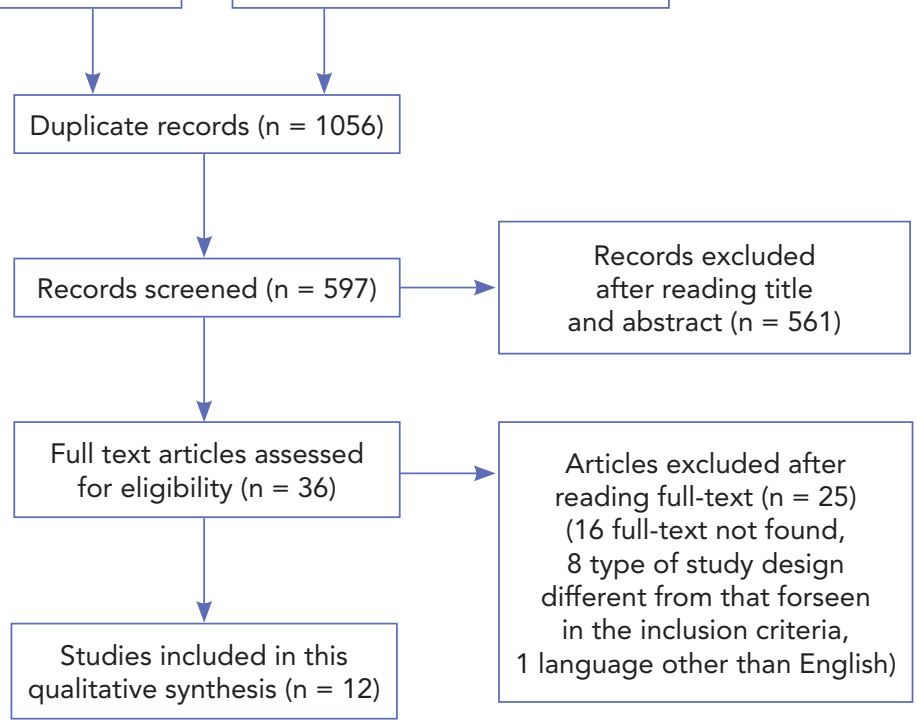

Figure 1. Flowchart of the included studies. 
(34) and an osteopathic counterstrain technique (39). The characteristics of these studies that are more relevant to this review are included in the following tables (tables I, II, III, IV).

Table I. Characteristics of the studies (RCT).

\begin{tabular}{|c|c|c|c|c|c|c|}
\hline Authors & Population & Intervention & Control & Outcome & Follow up & Results \\
\hline $\begin{array}{l}\text { Zemadanis } \mathrm{K} \text {, } \\
\text { et al. }\end{array}$ & $\begin{array}{l}\mathrm{N}^{\circ}=30 \\
\mathrm{SG}=15 \\
\mathrm{CG}=15 \\
\text { Post- } \\
\text { intervention } \\
\text { participants: } \\
\mathrm{SG}=15 \\
\mathrm{CG}=15 \\
\mathrm{Gender}(\mathrm{M} / \mathrm{F}): \\
\mathrm{SG}=6 / 9 \\
\mathrm{CG}=7 / 8 \\
\text { Age: } \\
\mathrm{SG}=33( \pm 7) \\
\mathrm{CG}=30( \pm 8)\end{array}$ & $\begin{array}{l}6 \text { sessions of } \\
\text { Mobilization } \\
\text { With Movement } \\
\text { (MWM) in a } 2 \\
\text { weeks period (3 } \\
\text { sessions each week). } \\
\text { The therapeutic } \\
\text { protocol consisted } \\
\text { of } 5 \text { pre-selected } \\
\text { MWM techniques } \\
\text { especially in weight- } \\
\text { bearing position in a } \\
\text { dosage of } 3 \text { sets of } 10 \\
\text { repetitions ( } 3 \text { X10). } \\
\text { In addition, self- } \\
\text { mobilization } \\
\text { techniques at home } \\
2 \text { to } 3 \text { times daily, } \\
\text { during the } 2 \text { weeks } \\
\text { study period in a } \\
\text { dosage of } 3 \times 10 .\end{array}$ & $\begin{array}{l}\text { Sham-form of the } \\
\text { therapeutic protocol, } \\
\text { guiding on the same } \\
\text { movements by the } \\
\text { participants, but } \\
\text { without therapist's } \\
\text { mobilization force. }\end{array}$ & $\begin{array}{l}\text { Pain (Numeric } \\
\text { Pain Rating Scale) } \\
\text { Functionality } \\
\text { (Lower Extremity } \\
\text { Functional Scale) }\end{array}$ & 2 weeks & $\begin{array}{l}\text { Pain and } \\
\text { functionality } \\
\text { score differences } \\
\text { between pre and } \\
\text { post treatment } \\
\text { measures were } \\
\text { significant for } \\
\text { MWM group, } \\
\text { in contrast to } \\
\text { SHAM group. } \\
\text { Differences } \\
\text { between } \\
\text { groups were } \\
\text { also significant, } \\
\text { on dependent } \\
\text { variables scores, } \\
\text { at post treatment } \\
\text { measurements }\end{array}$ \\
\hline $\begin{array}{l}\text { Weckstrom K, } \\
\text { et al. }\end{array}$ & $\begin{array}{l}\mathrm{N}^{\circ}=24 \\
\text { Gender } \\
(\mathrm{M} / \mathrm{F}): 14 / 10 \\
\text { Age: } \\
\mathrm{SG}=32( \pm 10) \\
\mathrm{CG}=34( \pm 6) \\
\mathrm{SG}=11 \\
\mathrm{CG}=13 \\
\text { Post- } \\
\text { intervention } \\
\text { participants: } \\
\mathrm{SG}=11 \\
\mathrm{CG}=9\end{array}$ & $\begin{array}{l}3 \text { treatments of radial } \\
\text { shockwawe therapy } \\
\text { (RSWT) at weekly } \\
\text { intervals. } \\
\text { At each of the } \\
\text { treatments a total } \\
\text { of } 4600 \text { pulses } \\
\text { were applied. } \\
\text { In addiction a } \\
\text { strength exercise } \\
\text { programme was used. }\end{array}$ & $\begin{array}{l}3 \text { treatments of } \\
\text { manual therapy at } \\
\text { weekly intervals. } \\
\text { Treatment procedure } \\
\text { was initiated by } \\
\text { massage of the ITB in } \\
\text { a proximal to distal } \\
\text { direction. } \\
\text { Trigger point therapy } \\
\text { through ischemic } \\
\text { compression was } \\
\text { applied for the } 3 \\
\text { most painful points } \\
\text { on the lateral thigh. } \\
\text { In addiction a } \\
\text { strength exercise } \\
\text { programme was used. }\end{array}$ & $\begin{array}{l}\text { Total pain } \\
\text { experienced } \\
\text { during treadmill } \\
\text { running was } \\
\text { selected as } \\
\text { the primary } \\
\text { outcome measure. } \\
\text { The secondary } \\
\text { outcome } \\
\text { measures were } \\
\text { defined as the } \\
\text { proportion } \\
\text { of subjects } \\
\text { performing } \\
\text { a pain-free } \\
\text { treadmill test. }\end{array}$ & $\begin{array}{l}4 \text { weeks, } \\
8 \text { weeks } \\
\text { and } 6 \text { months }\end{array}$ & $\begin{array}{l}\text { A significant } \\
\text { decrease in a } \\
\text { total pain }(51 \%) \\
\text { was experienced } \\
\text { by subjects in } \\
\text { the SWT group } \\
\text { in the period } \\
\text { from baseline } \\
\text { to week } 4 \text { and } \\
\text { from baseline } \\
\text { to week } 8 . \\
\text { The control } \\
\text { group showed } \\
\text { a tendency for } \\
\text { reduced pain } \\
\text { (61\%) from } \\
\text { baseline to } \\
\text { week } 4 \text { and } 8 . \\
\text { When } \\
\text { comparing MD } \\
\text { of decrease in } \\
\text { pain between } \\
\text { the } 2 \text { groups, } \\
\text { no significant } \\
\text { differences } \\
\text { was found. }\end{array}$ \\
\hline
\end{tabular}

\footnotetext{
$\mathrm{N}^{\circ}=$ number; $\mathrm{SG}=$ sperimental group; $\mathrm{CG}=$ control group; $\mathrm{M}=$ male; $\mathrm{F}=$ female.
} 
Table II. Characteristics of the studies (pre-post test).

\begin{tabular}{|c|c|c|c|c|}
\hline Authors & Population & Intervention & Outcome & Results \\
\hline Fredericson $\mathrm{M}$, et al. & $\begin{array}{l}\mathrm{N}^{\circ}=24 \\
\text { Gender }(\mathrm{M} / \mathrm{F}): 14 / 10 \\
\mathrm{~N}^{\circ} \mathrm{CG}=30 \\
\text { Gender }(\mathrm{M} / \mathrm{F}): 16 / 14\end{array}$ & $\begin{array}{l}6 \text { weeks standardized } \\
\text { rehabilitation program, } \\
\text { once per week. } \\
\text { The therapy protocol } \\
\text { consisted of local } \\
\text { application of ultrasound } \\
\text { with corticosteroid gel } \\
\text { for the first one or two } \\
\text { weeks, standard stretches } \\
\text { of the ITB, and a strength } \\
\text { exercise program (side- } \\
\text { lying hip abduction and } \\
\text { pelvic drops). }\end{array}$ & $\begin{array}{l}\text { Comparison of the force } \\
\text { between the two limbs of } \\
\text { the patients and with the } \\
\text { control group using the } \\
\text { hip abduction test with } \\
\text { dynamometer (Nicholas } \\
\text { Manual Muscle Tester) } \\
\text { after rehabilitation period. }\end{array}$ & $\begin{array}{l}\text { The results show a } \\
\text { significantly improved } \\
\text { difference in abductor } \\
\text { strength between } \\
\text { healthy limb and } \\
\text { pathological limb } \\
\text { at the end of the } \\
\text { treatment period. } \\
\text { At } 6 \text { weeks, } 22 \text { of } \\
24 \text { athletes were } \\
\text { pain free and had } \\
\text { started a return to } \\
\text { running protocol; } \\
\text { follow up by phone } \\
\text { at } 6 \text { months found no } \\
\text { recurrences of ITBS. }\end{array}$ \\
\hline Beers A, et al. & $\begin{array}{l}\mathrm{N}^{\circ}=16 \\
\text { Gender }(\mathrm{M} / \mathrm{F}): 5 / 11 \\
\text { Age: } 20-53(\text { average } 33.7)\end{array}$ & $\begin{array}{l}\text { The rehabilitation } \\
\text { programme was focused } \\
\text { on improving hip abductor } \\
\text { strength } 1 \text { or } 2 \text { times per } \\
\text { week for } 6 \text { weeks (side- } \\
\text { lying hip abduction } \\
\text { exercise, a standing pelvic } \\
\text { stabilization exercise and } \\
\text { forward-backward lunges). } \\
2 \text { ITB stretches and } \\
\text { ultrasound are used. }\end{array}$ & $\begin{array}{l}\text { Allan McGavin Health } \\
\text { Status Index (AMI) for } \\
\text { functionality and a hand- } \\
\text { held dynamometer for } \\
\text { abductor strength. }\end{array}$ & $\begin{array}{l}\text { Although not having } \\
\text { a control group, } \\
\text { this study shows a } \\
\text { success in decreasing } \\
\text { the differences in } \\
\text { strength between the } \\
\text { limb affected by ITBS } \\
\text { and the healthy one, } \\
\text { even if they can also } \\
\text { be correlated with } \\
\text { other factors. }\end{array}$ \\
\hline SchwellnusM, et al. & $\begin{array}{l}\mathrm{N}^{\circ}=20 \\
\text { Participants who } \\
\text { have competed the } \\
\text { treatment }=17\end{array}$ & $\begin{array}{l}\text { Two groups (A and B), } \\
\text { where compared to group } \\
\text { B (treated with rest, ice, } \\
\text { stretching and ultrasound) } \\
\text { deep cross massage } \\
\text { treatments are added } \\
\text { to group A. } \\
2 \text { week } \\
\text { rehabilitation period. }\end{array}$ & $\begin{array}{l}\text { Pain scale was a visual } \\
\text { analogue scale marked } \\
\text { from } 0 \text { to } 10 \text { where } 0 \\
\text { represented no pain and } \\
10 \text { unbearable pain. } \\
\text { Functional treadmill } \\
\text { running tests were } \\
\text { performed on days } 0 \text {, } \\
3,7 \text { and } 14 \text {. }\end{array}$ & $\begin{array}{l}\text { There was a } \\
\text { significant decrease } \\
\text { in pain scores and in } \\
\text { pain during running } \\
\text { in both groups, } \\
\text { but no significant } \\
\text { difference was } \\
\text { observed between } \\
\text { the } 2 \text { groups. }\end{array}$ \\
\hline
\end{tabular}

$\mathrm{N}^{\circ}=$ number; $\mathrm{SG}=$ sperimental group; $\mathrm{CG}=$ control group; $\mathrm{M}=$ male; $\mathrm{F}=$ female. 
Table III. Characteristics of the studies (case report and case series).

\begin{tabular}{|c|c|c|c|c|}
\hline Authors & Population & Intervention & Outcome & Results \\
\hline Shamus J, et al. & $\begin{array}{l}\mathrm{N}^{\circ}=2 \\
\text { Gender: } \mathrm{F} \\
\text { Age: } 36 \text { and } 41\end{array}$ & $\begin{array}{l}\text { Approach with a complete } \\
\text { and general evaluation } \\
\text { of the patient and an } \\
\text { intervention based on } \\
\text { the correction of the } \\
\text { disfunctions found in the } \\
\text { evaluation (neuromuscolar } \\
\text { reeducation, detonification, } \\
\text { muscle energy techniques, } \\
\text { counterstrain techniques, } \\
\text { muscle strengthening and } \\
\text { stretching). }\end{array}$ & Return to sport. & $\begin{array}{l}\text { This double case } \\
\text { report demonstrates } \\
\text { the effectiveness of } \\
\text { a global and specific } \\
\text { approach according to } \\
\text { the patient's muscular and } \\
\text { joint dysfunctions and } \\
\text { alterations. }\end{array}$ \\
\hline Winslow J, et al. & $\begin{array}{l}\mathrm{N}^{\circ}=4 \\
\text { Gender: } \mathrm{F} \\
\text { Age: } \\
\text { between } 27 \text { and } 43\end{array}$ & $\begin{array}{l}\text { Patients were treated three } \\
\text { times a week for three } \\
\text { weeks and the sessions } \\
\text { lasted approximately } 40 \\
\text { minutes. They received soft } \\
\text { tissue mobilization only } \\
\text { and were not given any } \\
\text { exercises. }\end{array}$ & $\begin{array}{l}\text { Functionality } \\
\text { (Lower Extremity } \\
\text { Functional Scale, } \\
\text { Global Rating of } \\
\text { Change Scale). }\end{array}$ & $\begin{array}{l}\text { At } 4 \text { weeks, } 3 \text { of the } \\
\text { athletes were able to run } \\
\text { on treadmill for three } \\
\text { miles without having to } \\
\text { stop due to lateral knee } \\
\text { pain. The } 3 \text { athletes } \\
\text { improved } 9 \text { to } 19 \text { points } \\
\text { on the LEFS, } 3 \text { to } 5 \text { on } \\
\text { the GRCS and improved } \\
\text { in hamstring and ITB } \\
\text { flexibility. }\end{array}$ \\
\hline Darrel J, et al. & $\begin{array}{l}\mathrm{N}^{\circ}=1 \\
\text { Gender: } \mathrm{F} \\
\text { Age: } 36\end{array}$ & $\begin{array}{l}\text { Running gait retraining } \\
\text { with step rate manipulation, } \\
\text { increasing the subject's } \\
\text { running cadence from } 168 \\
\text { to } 176 \text { steps per minute } \\
\text { ( } \% \% \text { more or } 8 \text { more steps). } \\
\text { Treatment also included } \\
\text { iliotibial band flexibility and } \\
\text { multi-plane eccentric lower } \\
\text { extremity strengthening. }\end{array}$ & $\begin{array}{l}\text { Pain (VAS), } \\
\text { strength, } \\
\text { functionality (LEFS) } \\
\text { and improved } \\
\text { running mechanics. }\end{array}$ & $\begin{array}{l}\text { Running mechanics } \\
\text { improved considerably at } \\
\text { week } 4 \text { and at week } 6 \text { the } \\
\text { patient is able to run long } \\
\text { distances without pain. } \\
\text { This case demonstrated } \\
\text { that a } 5 \% \text { increased step } \\
\text { rate above preferred along } \\
\text { with a home exercise } \\
\text { of strengthening and } \\
\text { stretching improved } \\
\text { running mechanics and } \\
\text { reduced knee pain in a } \\
\text { distance runner. }\end{array}$ \\
\hline Pettitt R, et al. & $\begin{array}{l}\mathrm{N}^{\circ}=1 \\
\text { Gender: } \mathrm{F} \\
\text { Age: } 19\end{array}$ & $\begin{array}{l}\text { Neuromuscolar approach } \\
\text { with muscle stretching and } \\
\text { strengthening, massage, } \\
\text { soft tissue mobilization, } \\
\text { nonweightbearing } \\
\text { and weightbearing } \\
\text { therapeutic exercises and } \\
\text { neuromuscolar electric } \\
\text { stimulation. }\end{array}$ & $\begin{array}{l}\text { Return to sport free } \\
\text { of symptoms. }\end{array}$ & $\begin{array}{l}\text { This type of intervention } \\
\text { and neuromuscular } \\
\text { approach allowed the } \\
\text { return to sporting } \\
\text { activity at the } 10 \text { th week } \\
\text { without symptoms. }\end{array}$ \\
\hline
\end{tabular}




\begin{tabular}{|c|c|c|c|c|}
\hline Authors & Population & Intervention & Outcome & Results \\
\hline Hunter L, et al. & & $\begin{array}{l}9 \text { real-time running- } \\
\text { retraining sessions in } 4 \\
\text { weeks were implemented } \\
\text { based on the biomechanical } \\
\text { alterations of the } \\
\text { participant's symptomatic } \\
\text { lower limb, including } \\
\text { pelvic and knee movement } \\
\text { in the transverse plane, as } \\
\text { well as foot movement in } \\
\text { the frontal plane. Real- } \\
\text { time visual feedback of } \\
\text { the pelvic-rotation angle } \\
\text { was provided during the } \\
\text { running-retraining sessions. }\end{array}$ & $\begin{array}{l}\text { 3-dimensional } \\
\text { lower-extremity } \\
\text { running kinematics, } \\
\text { pain on a verbal } \\
\text { analogue scale } \\
\text { (VAS), functionality } \\
\text { (LEFS) during } \\
\text { running on a } \\
\text { treadmill. }\end{array}$ & $\begin{array}{l}\text { The real-time running- } \\
\text { retraining program } \\
\text { improved pain while } \\
\text { running, as well as } \\
\text { function, and was } \\
\text { effective in addressing the } \\
\text { lower-limb biomechanical } \\
\text { alterations of the knee } \\
\text { and foot. }\end{array}$ \\
\hline Pedowitz R, et al. & & $\begin{array}{l}\text { Osteopathic manipulative } \\
\text { treatment (OMT) of } \\
\text { counterstrain, } 2 \text { or } 3 \text { times } \\
\text { per week for } 2 \text { weeks. }\end{array}$ & $\begin{array}{l}\text { Questionnaire } \\
\text { to complete on } \\
\text { each day (on both } \\
\text { treatment and } \\
\text { nontreatment } \\
\text { days) during the } 2 \\
\text { weeks treatment } \\
\text { period. } 12 \text { question } \\
\text { were listed about } \\
\text { pain, application } \\
\text { of treatment } \\
\text { modalities, type } \\
\text { of athletic activity } \\
\text { performed, } \\
\text { subjective responses } \\
\text { concerning mood nd } \\
\text { ability to sleep and } \\
\text { perform activities of } \\
\text { daily living. }\end{array}$ & $\begin{array}{l}\text { During the treatment } \\
\text { period, the patient rated } \\
\text { his pain severity as } 0 . \\
\text { During the first follow up } \\
\text { appointment, on day } 21 \text {, } \\
\text { he reported that he had } \\
\text { been feeling well and had } \\
\text { returned to his normal, } \\
\text { full running activity by } \\
\text { day } 18 \text {. In the next } 3 \\
\text { weeks he had been free } \\
\text { of pain, feeling happier } \\
\text { overall and improved his } \\
\text { ability to sleep at night } \\
\text { and to perform the regular } \\
\text { activities of daily life. }\end{array}$ \\
\hline
\end{tabular}


Table IV. Main treatment for conservative rehabilitation treatments of iliotibial band syndrome.

\begin{tabular}{|c|c|c|c|}
\hline Type of study & Authors & Population & Intervention \\
\hline RCT & Zemadanis $\mathrm{K}$, et al. & $\begin{array}{l}\mathrm{N}^{\circ}=30 \\
\mathrm{SG}=15 \\
\mathrm{CG}=15 \\
\text { Post-intervention participants: } \\
\mathrm{SG}=15 \\
\mathrm{CG}=15 \\
\mathrm{Gender}(\mathrm{M} / \mathrm{F}): \\
\mathrm{SG}=6 / 9 \\
\mathrm{CG}=7 / 8 \\
\text { Age: } \\
\mathrm{SG}=33( \pm 7) \\
\mathrm{CG}=30( \pm 8)\end{array}$ & $\begin{array}{l}6 \text { sessions of Mobilization With Movement } \\
(\mathrm{MWM}) \text { in a } 2 \text { weeks period ( } 3 \text { sessions each } \\
\text { week). The therapeutic protocol consisted of } \\
5 \text { pre-selected MWM techniques especially in } \\
\text { weight-bearing position in a dosage of } 3 \text { sets of } 10 \\
\text { repetitions }(3 \times 10) \text {. } \\
\text { In addition, self-mobilization techniques at home } 2 \\
\text { to } 3 \text { times daily, during the } 2 \text { weeks study period in } \\
\text { a dosage of } 3 \times 10 \text {. }\end{array}$ \\
\hline RCT & Weckstrom K, et al. & $\begin{array}{l}\mathrm{N}^{\circ}=24 \\
\text { Gender }(\mathrm{M} / \mathrm{F}): 14 / 10 \\
\text { Age: } \\
\mathrm{SG}=32( \pm 10) \\
\mathrm{CG}=34( \pm 6) \\
\mathrm{SG}=11 \\
\mathrm{CG}=13 \\
\text { Post-intervention participants: } \\
\mathrm{SG}=11 \\
\mathrm{CG}=9\end{array}$ & $\begin{array}{l}3 \text { treatments of radial shockwawe therapy (RSWT) } \\
\text { at weekly intervals. } \\
\text { At each of the treatments a total of } 4600 \text { pulses } \\
\text { were applied. } \\
\text { In addiction a strength exercise } \\
\text { programme was used. }\end{array}$ \\
\hline PRE-POST TEST & Fredericson $\mathrm{M}$, et al. & $\begin{array}{l}\mathrm{N}^{\circ}=24 \\
\text { Gender }(\mathrm{M} / \mathrm{F}): 14 / 10 \\
\mathrm{~N}^{\circ} \mathrm{CG}=30 \\
\text { Gender }(\mathrm{M} / \mathrm{F}): 16 / 14\end{array}$ & $\begin{array}{l}6 \text { weeks standardized rehabilitation program, } \\
\text { once per week. } \\
\text { The therapy protocol consisted of local application } \\
\text { of ultrasound with corticosteroid gel for the first } \\
\text { one or two weeks, standard stretches of the ITB, } \\
\text { and a strength exercise program (side-lying hip } \\
\text { abduction and pelvic drops). }\end{array}$ \\
\hline PRE-POST TEST & Beers A, et al. & $\begin{array}{l}\mathrm{N}^{\circ}=16 \\
\text { Gender }(\mathrm{M} / \mathrm{F}): 5 / 11 \\
\text { Age: } 20-53 \text { (average } 33.7)\end{array}$ & $\begin{array}{l}\text { The rehabilitation programme was focused on } \\
\text { improving hip abductor strength } 1 \text { or } 2 \text { times } \\
\text { per week for } 6 \text { weeks (side-lying hip abduction } \\
\text { exercise, a standing pelvic stabilization exercise } \\
\text { and forward-backward lunges). } 2 \text { ITB stretches and } \\
\text { ultrasound are used }\end{array}$ \\
\hline PRE-POST TEST & Schwellnus M, et al. & $\begin{array}{l}\mathrm{N}^{\circ}=20 \\
\text { Participants who have competed } \\
\text { the treatment }=17\end{array}$ & $\begin{array}{l}\text { Two groups (A and B), where compared to group } \\
\text { B (treated with rest, ice, stretching and ultrasound) } \\
\text { deep cross massage treatments are added } \\
\text { to group A. } \\
2 \text { week rehabilitation period. }\end{array}$ \\
\hline Case series & Shamus J, et al. & $\begin{array}{l}\mathrm{N}^{\circ}=2 \\
\text { Gender: } \mathrm{F} \\
\text { Age: } 36 \text { and } 41\end{array}$ & $\begin{array}{l}\text { Approach with a complete and general evaluation } \\
\text { of the patient and an intervention based on } \\
\text { the correction of the disfunctions found in } \\
\text { the evaluation (neuromuscolar reeducation, } \\
\text { detonification, muscle energy techniques, } \\
\text { counterstrain techniques, muscle strengthening and } \\
\text { stretching). }\end{array}$ \\
\hline Case series & Winslow J, et al. & $\begin{array}{l}\mathrm{N}^{\circ}=1 \\
\text { Gender: } \mathrm{F} \\
\text { Age: between } 27 \text { and } 43\end{array}$ & $\begin{array}{l}\text { Patients were treated three times a week for three } \\
\text { weeks and the sessions lasted approximately } 40 \\
\text { minutes. They received soft tissue mobilization } \\
\text { only and were not given any exercises. }\end{array}$ \\
\hline
\end{tabular}




\begin{tabular}{|c|c|c|c|}
\hline Type of study & Authors & Population & Intervention \\
\hline Case report & Darrel J, et al. & $\begin{array}{l}\mathrm{N}^{\circ}=1 \\
\text { Gender: } \mathrm{F} \\
\text { Age: } 36\end{array}$ & $\begin{array}{l}\text { Running gait retraining with step rate } \\
\text { manipulation, increasing the subject's running } \\
\text { cadence from } 168 \text { to } 176 \text { steps per minute }(5 \% \\
\text { more or } 8 \text { more steps). Treatment also included } \\
\text { iliotibial band flexibility and multi-plane eccentric } \\
\text { lower extremity strengthening. }\end{array}$ \\
\hline Case report & Pettitt R, et al. & $\begin{array}{l}\mathrm{N}^{\circ}=1 \\
\text { Gender: } \mathrm{F} \\
\text { Age: } 19\end{array}$ & $\begin{array}{l}\text { Neuromuscolar approach with muscle stretching } \\
\text { and strengthening, massage, soft tissue } \\
\text { mobilization, nonweightbearing and weightbearing } \\
\text { therapeutic exercises and neuromuscolar electric } \\
\text { stimulation. }\end{array}$ \\
\hline Case report & Hunter L, et al. & $\begin{array}{l}\mathrm{N}^{\circ}=1 \\
\text { Gender: } \mathrm{F} \\
\text { Age: } 38\end{array}$ & $\begin{array}{l}9 \text { real-time running-retraining sessions in } 4 \text { weeks } \\
\text { were implemented based on the biomechanical } \\
\text { alterations of the participant's symptomatic lower } \\
\text { limb, including pelvic and knee movement in the } \\
\text { transverse plane, as well as foot movement in the } \\
\text { frontal plane. Real-time visual feedback of the } \\
\text { pelvic-rotation angle was provided during the } \\
\text { running-retraining sessions. }\end{array}$ \\
\hline Case report & Pedowitz R, et al. & $\begin{array}{l}\mathrm{N}^{\circ}=1 \\
\text { Gender: } \mathrm{M} \\
\text { Age: } 30\end{array}$ & $\begin{array}{l}\text { Osteopathic manipulative treatment (OMT) of } \\
\text { counterstrain, } 2 \text { or } 3 \text { times per week for } 2 \text { weeks. }\end{array}$ \\
\hline
\end{tabular}

$\mathrm{N}^{\circ}=$ number; $\mathrm{SG}=$ sperimental group; $\mathrm{CG}=$ control group; $\mathrm{M}=$ male; $\mathrm{F}=$ female.

\section{Risk of bias within studies}

Study quality and risks of bias were assessed using the Jadad scale and Pedro scale. In general, the two RCTs showed good quality, confirmed by the scales used. In fact, Weckstrom's study (7) obtained scores of $3 / 5$ in the Jadad scale and 7/11 in the Pedro scale. The study of Kostantinos et al. (37) obtained scores of 5/5 and 9/11, respectively.

\section{DISCUSSION}

Iliotibial band syndrome is one of the most common injuries to the lower extremities of runners and other athletes. The syndrome accounts for almost $12 \%$ of all reported overuse injuries in runners (39). However, it is associated with a variety of activities, including cycling, hockey, swimming, rowing, basketball, tennis and soccer $(5,6)$.

The aim of this research is to analyse studies with conservative physiotherapy treatments in order to identify the most effective ones, with the ultimate goal of reducing the suspension time of athletes' sports activity. In fact, numerous athletes are forced to interrupt their practice for too long because of iliotibial band syndrome. Only rehabilitation studies have been included in this review: articles on the use of anti-inflammatories $(35,40)$, and invasive treatments such as corticosteroid injections (41) have been excluded.
In the acute initial phase, treatment is based on management and reduction of inflammation, during which physical activity is suspended and rest and ice are recommended (39, $40,42)$. Some authors considered the use of physical therapy, specifically ultrasound, in the first part of the rehabilitation programme $(35,42)$. In an RCT, Weckstrom and Soderstrom compared two treatment protocols for iliotibial band syndrome (ITBS): radial shockwave therapy (RSWT) and manual therapy (ManT), highlighting an important reduction of pain, without, however, obtaining significant differences between the two groups (7).

We can safely assert that it is important in the acute phase to treat symptoms and inflammation by suspending sports (or, at minimum, by reducing running distances), using ice, taking anti-inflammatory drugs (on advice of a doctor or orthopaedic specialist) and resorting to instrumental physical therapy.

In the subacute phase, techniques of muscle stretching are introduced $(1,42)$ for obtaining the second goal of the rehabilitation programme: to identify the cause of the irritative and inflammatory process in the insertion of iliotibial band (ITB). In this case, an accurate medical history and a complete assessment of the patient are important. In a double case report, Jennifer and Erik Shamus have oriented their treatment on the correction of joint and muscular 
dysfunctions found at the proximal and distal levels with neuromuscular re-education, detonification, muscle energy techniques, counterstrain techniques, muscle strengthening and stretching (34). This represented the only study with joint mobilization techniques such as hight velocity, low amplitude (HVLA) in the context of a global approach, until Zemadanis and Betsos treated ITBS in 2017 with manual therapy techniques. Mulligan techniques of mobilization with movement (MWM) were used, focusing attention on knee and hip movements, in motions contrary to those that according to the literature lead to an increase in tension on the ITB adduction of hip and knee rotation (37). In this RCT, a two-week treatment was carried out with three sessions per week, using five Mobilization With Movement (MWM) techniques in three sets of ten repetitions, compared with a control group that performed the same movements as the experimental group but without the mobilization of the therapist. The results demonstrate significant improvements in the Numeric Pain Rating Scale (NPRC) and Lower Extremity Functional Scale (LEFS) scales compared to $\mathrm{T}_{0}$ and significant differences compared to the control group.

Many authors have found a correlation between hip abductor weakness and ITBS, focusing their rehabilitation programmes on muscle strengthening as the main intervention $(30,42)$ or as an integral part of the rehabilitation programme $(7,32-34)$. Manual therapy is another possible solution to treatment. Soft tissue mobilization is a potential technique described in a study with four athletes. The results showed significant improvements in the LEFS and Global Rating of Change Scale (GRCS) scales at a four-week follow-up (Winslow, 2014). In another study, two groups were compared, in which group A received, in addition to the basic protocol of group B with rest, ice, stretching and ultrasound, deep transverse massage treatment. The report did not highlight significant differences between the two groups (35). Other manual therapy treatments are present in the Weckstrom study in the control group with massage and ischemic compression of the trigger points, with statistically significant improvements (7). Another study including manual therapy techniques and that has obtained statistically significant positive results is the one mentioned previously with Mulligan techniques from Zemadanis and Betsos (37).

Some authors have focused solely on running. In a study conducted by Darrel J. Allen (2014) (33), the goal was to increase the frequency of steps per minute up to $176 / \mathrm{min}$, indicated as ideal in a study by Heiderscheidt et al. (2011) to not overload the knee and improve running mechanics. Another study aimed at correcting the mechanics of the race was conducted by Hunter and colleagues, correcting the aberrations that emerged during observation and evaluation of the videos through verbal and visual feedback (38). Both studies achieved good results, leading to an improvement in pain symptoms (VAS) and functionality (LEFS) and facilitating the return to sports.

An interesting study is the one conducted by Pedowitz, who, in the context of a case report, has achieved significant improvements in pain thanks to osteopathic manipulative treatment with the use of the counterstrain technique (39). Finally, in the most recent RCT, conducted by McKay et al. on female runners, patients were divided into three equal treatment groups: ITB stretching, conventional exercise, and experimental hip strengthening exercise. Numeric pain rating scale, lower extremity functional scale, dynamometer, and Y-balance test ${ }^{\mathrm{TM}}$ were evaluated. Authors found no statistical differences between the three groups. The subjects who underwent experimental hip strengthening exercises consistently showed improvements in outcome measures, and never scored less than the other two groups (31).

\section{Limitations}

The limitations of this study concern several factors, the main one being the reduced number of randomized clinical trials found in the literature, which moreover have a low sample number of patients. The two trials included in the review did not lead to a quantitative study, as the two studies do not present a common measurement of the outcome. Another limitation is the presence of numerous case reports and case series, which, although providing important information for the purposes of rehabilitation treatment, do not represent significant and relevant studies. Moreover, papers for a quite common syndrome are few to give frank conclusions even because the treatment are different and variable and some studies published after search strategy have not been considered $(31,43,44)$. Finally, a division between proximal and distal cases was not made, future studies could consider this distinction.

\section{CONCLUSIONS}

Based on the studies included in this review, the validity and efficacy of the conservative rehabilitation treatment of ITBS has been demonstrated.

More precisely, as regards the acute phase and the management of pain and inflammation, the most relevant study, being a randomized clinical trial, was the one conducted by Weckström (7) and colleagues on the use of shockwaves. Obviously, in this phase, rest and the use of ice are strongly recommended. In the subacute phase, the same rehabilitation programme was focused on improving hip abductor strength and improving the elasticity of TFL. 
Manual therapy techniques are present and have led to positive results. The most relevant study, based on the pyramid of evidence, was a randomized clinical trial conducted by Zemadanis and Betsos (37) who proposed the use of Mulligan techniques on hips and knees.

The other studies in this review, although having provided important information for the efficacy of the treatment, need to be expanded to include larger samples and control group comparisons to increase the number of studies present in the literature and subsequently facilitate a quantitative assessment. This new research would help in the identification of the best rehabilitation intervention for patients with ITBS and could promote an early return to sports activity by reducing suspension time, which is the main problem for athletes who are affected by this pathology. The study meets the ethical standards of the journal (45).

\section{ETHICS}

Authors certify that all applicable institutional and governmental regulations concerning the ethical use of human volunteers were followed during the course of this research.

\section{REFERENCES}

1. Fredericson M, Wolf C. Iliotibial band syndrome in runners: Innovations in treatment. Sports Med 2005;35(5):451-9.

2. Beals C, Flanigan D. A Review of Treatments for Iliotibial Band Syndrome in the Athletic Population. J Sports Med (Hindawi Publ Corp) 2013;2013:367169.

3. Fredericson M, Weir A. Practical management of iliotibial band friction syndrome in runners. Clin J Sport Med 2006;16(3):261-8.

4. van Gent RN, Siem D, van Middelkoop M, van Os AG, Bierma-Zeinstra SM, Koes BW. Incidence and determinants of lower extremity running injuries in long distance runners: A systematic review. Br J Sports Med 2007;41(8):469-80; discussion 480.

5. Barber FA, Sutker A. N. Iliotibial band syndrome (Syndrome de la bandelette de Maissiat). Sports Med 1992;14(2):144-8.

6. Taunton JE, Ryan MB, Clement DB, McKenzie DC, LloydSmith DR, Zumbo BD. A retrospective case-control analysis of 2002 running injuries. Br J Sports Med 2002;36(2):95-101.

7. Weckström K, Söderström J. Radial extracorporeal shockwave therapy compared with manual therapy in runners with iliotibial band syndrome. J Back Musculoskelet Rehabil 2016;29(1):161-70.

8. Lininger MR, Miller MG. Iliotibial band syndrome in the athletic population: Strengthening and rehabilitation exercises. Strength Cond J 2009;31(3):43-46.

9. Hamill J, Miller R, Noehren B, Davis I. A prospective study of iliotibial band strain in runners. Clin Biomech (Bristol, Avon) 2008;23(8):1018-25

10. MacMahon JM, Chaudhari AM, Andriacchi TP. Biomechanical Injury Predictors for Marathon Runners: Striding Towards
All procedures followed were in accordance with the ethical standards of the responsible committee on human experimentation (institutional and national) and with the Helsinki Declaration of 1975, as revised in 2008. Informed consent was obtained from all participants for being included in the study. Institutional Review Board approval was not required because the administration of these tool was part of the usual process of assessment of these individuals in clinical practice, the research involved the analysis of data collected such that individual subjects cannot be identified in any way.

\section{FUNDINGS}

The authors state that this work has not received any funding. The authors of this manuscript declare no relationships with any companies, whose products or services may be related to the subject matter of the article.

\section{CONFLICT OF INTERESTS}

The authors declare that they have no conflict of interests.

Iliotibial Band Syndrome Injury Prevention. In: XVIII International Symposium of Biomechanics in Sports, 2000.

11. Baker RL, Souza RB, Fredericson M. Iliotibial band syndrome: soft tissue and biomechanical factors in evaluation and treatment. PM R 2011;3(6):550-61.

12. van der Worp MP, van der Horst N, de Wijer A, Backx FJ, Nijhuis-van der Sanden MW. Iliotibial band syndrome in runners: a systematic review. Sports Med 2012;42(11):969-92.

13. Balachandar V, Hampton H, Riaz O, Woods S. Iliotibial Band Friction Syndrome: A Systematic Review and Meta-analysis to evaluate lower-limb biomechanics and conservative treatment. MLTJ 2019;9 (2):181-193.

14. Marquez MA, De Santis R, Ammendola V, et al. Cross-cultural adaptation and validation of the "Spinal Cord Injury-Falls Concern Scale" in the Italian population. Spinal Cord 2018;56(7):712-718.

15. Puledda F, Viganò A, Celletti C, et al. A study of migraine characteristics in joint hypermobility syndrome a.k.a. Ehlers-Danlos syndrome, hypermobility type. Neurol Sci 2015;36(8):1417-24.

16. Ruggieri M, Palmisano B, Fratocchi G, et al. Validated Fall Risk Assessment Tools for Use with Older Adults: A Systematic Review. Phys Occup Ther Geriatr 2018;36:331-353.

17. Nobilia M, Culicchia G, Tofani M, et al. Italian version of the jebsen-taylor hand function test for the assessment of hand disorders: A cross-sectional study. Am J Occup Ther 2019;73(3):7303205080p1-7303205080p6.

18. Tramontano M, Bergamini E, Iosa M, Belluscio V, Vannozzi G, Morone G. Vestibular rehabilitation training in patients with subacute stroke: A preliminary randomized controlled trial. NeuroRehabilitation 2018;43(2):247-254. 
19. Castelnuovo G, Giusti EM, Manzoni GM, et al. What Is the Role of the Placebo Effect for Pain Relief in Neurorehabilitation? Clinical Implications From the Italian Consensus Conference on Pain in Neurorehabilitation. Front Neurol 2018;9:310.

20. Tofani M, Galeoto G, Cazzetta D, Berardi A, Sansoni J, Valente D. Validation of the Pediatric Evaluation of Disability Inventory in an Italian Population with Autism Spectrum Disorder: a Cross-Sectional Study. Clin Ter 2019;170(6):e460-e464.

21. Galeoto G, Rumiati R, Sabella M, Sansoni J. The use of a dedicated platform to evaluate health-professions university courses. In: Advances in Intelligent Systems and Computin, 2019:pp. 275-284

22. Savona A, Ferralis L, Saffioti M, et al. Evaluation of intraand inter-rater reliability and concurrent validity of the Italian version of the Jebsen-Taylor Hand Function Test in adults with rheumatoid arthritis. Hand Ther 2019;24(2):175899831984355.

23. Berardi A, Galeoto G, Guarino D, et al. Construct validity, test-retest reliability, and the ability to detect change of the Canadian Occupational Performance Measure in a spinal cord injury population. Spinal Cord Ser Cases 2019;5:52.

24. Romagnoli G, Leone A, Romagnoli G, et al. Occupational Therapy's efficacy in children with Asperger's syndrome: a systematic review of randomized controlled trials. Clin Ter 2019;170(5):e382-e387.

25. Berardi A, Saffioti M, Tofani M, et al. Internal consistency and validity of the Jebsen-Taylor hand function test in an Italian population with hemiparesis. NeuroRehabilitation 2019;45(3):331-339.

26. Amedoro A, Berardi A, Conte A, et al. The effect of aquatic physical therapy on patients with multiple sclerosis: A systematic review and meta-analysis. Mult Scler Relat Disord 2020;41:102022.

27. Galeoto G, Turriziani S, Berardi A, et al. Levels of Cognitive Functioning Assessment Scale: Italian cross-cultural adaptation and validation. Ann Ing 2020;32(1):16-26.

28. Tofani M, Candeloro C, Sabbadini M, et al. A study validating the Italian version of the Level of Sitting Scale in children with cerebral palsy. Clin Rehabil 2019;33(11):1810-1818.

29. Fredericson M, Cookingham CL, Chaudhari AM, Dowdell BC, Oestreicher N, Sahrmann SA. Hip abductor weakness in distance runners with iliotibial band syndrome. Clin J Sport Med 2000;10(3):169-75.

30. Beers A, Ryan M, Kasubuchi Z, Fraser S, Taunton JE. Effects of Multi-modal Physiotherapy, Including Hip Abductor Strengthening, in Patients with Iliotibial Band Friction Syndrome. Physiother Can 2008;60(2):180-188.

31. McKay J, Maffulli N, Aicale R, Taunton J. Iliotibial band syndrome rehabilitation in female runners: a pilot randomized study. J Orthop Surg Res 2020;15(1):188.
32. Pettitt R, Dolski A. Corrective Neuromuscular Approach to the Treatment of Iliotibial Band Friction Syndrome: A Case Report. J Athl Train 2000;35(1):96-99.

33. Allen DJ. Treatment of distal iliotibial band syndrome in a long distance runner with gait re-training emphasizing step rate manipulation. Int J Sports Phys Ther 2014;9(2):222-31.

34. Shamus J, Shamus E. The management of iliotibial band syndrome with a multifaceted approach: a double case report. Int J Sports Phys Ther 2015;10(3):378-90.

35. Schwellnus M, Mackintosh L, Mee J. Deep Transverse Frictions in the Treatment of lliotibial Band Friction Syndrome in Athletes: A clinical trial. Physiother (United Kingdom) 1992;78(8):564-568.

36. Winslow J. Treatment of lateral knee pain using soft tissue mobilization in four female triathletes. Int J Ther Massage Bodywork 2014; 7(3):25-31.

37. Zemadanis K, Betsos T. Short-Term Effects of Mobilization-with-Movement (MWM) and Auto-MWM Application in Recreational Runners with Iliotibial Band Syndrome. Int J Physiother 2017;4(6)327-334.

38. Hunter L, Louw QA, van Niekerk SM. Effect of running retraining on pain, function, and lower-extremity biomechanics in a female runner with iliotibial band syndrome. J Sport Rehabil 2014;23(2):145-57.

39. Pedowitz RN. Use of osteopathic manipulative treatment for iliotibial band friction syndrome. J Am Osteopath Assoc 2005;105(12):563-7.

40. Bischoff C, Prusaczyk WK, Sopchick TL, Pratt NC, Goforth HW. Comparison of phonophoresis and knee immobilization in treating iliotibial band syndrome. Sport Med Train Rehabil 1995;6(1):1-6.

41. Gunter P, Schwellnus MP. Local corticosteroid injection in iliotibial band friction syndrome in runners: a randomised controlled trial. Br J Sports Med 2004;38(3):269-72; discussion 272.

42. Fredericson M, Guillet M, DeBenedictis L. Quick solutions for iliotibial band syndrome. Phys Sport 2000;28(2):52-68

43. Everhart JS, Di Bartola A, Chaudhari AMW, Flanigan D. Iliotibial band syndrome: Can the lateral femoral epicondyle play a role? An anatomic study of individual variation in epicondyle prominence. MLTJ 2019:49-54.

44. Pegrum J, Self A, Hall N. Iliotibial band syndrome. BMJ 2019;364:1980.

45. Padulo J, Oliva F, Frizziero A, Maffulli N. Muscles, Ligaments and Tendons Journal - Basic principles and recommendations in clinical and field Science Research: 2018 update. MLTJ 2018;8(3):305-307. 